\title{
Developing Criminal Policy on Illegal Fishing Counter- measures under the New Normal Order in Indonesia: A Non-penal Perspective
}

\author{
Maya Shafira ${ }^{1}$, Sunarto $^{2}$, Mashuril Anwar ${ }^{3}$ \\ \{maya.shafira@fh.unila.ac.id ${ }^{1}$, sunarto.54@fh.unila.ac.id², mashurilanwar97@gmail.com ${ }^{3}$ \} \\ Criminal Law Department, University of Lampung, Lampung, Indonesia ${ }^{1}$, Criminal Law Department, \\ University of Lampung, Lampung, Indonesia ${ }^{2}$, Criminal Law Department, University of Lampung, \\ Lampung, Indonesia ${ }^{3}$
}

\begin{abstract}
This article has the purpose of studying the ideal model for illegal fishing countermeasures in the 'new normal' order. Based on the findings of this research, in the 'new normal' order the current penal-oriented criminal policy on illegal fishing countermeasures can potentially raise various issues, both at the level of application as well as execution. It is therefore concluded that for optimal law enforcement against perpetrators of illegal fishing in the current era of 'new normal' order, criminal policy on illegal fishing counter-measures needs to emphasize non-penal measures by enhancing information technology-based control, strengthening deliberative democracy, and providing environment-oriented guidance.
\end{abstract}

Keywords: new normal, criminal policy, illegal fishing.

\section{Introduction}

Ever since the first case in Wuhan on December 8, 2019, the Corona Virus Disease or COVID-19 has been receiving attention in the Indonesian as well as the global community [1]. Google search related to COVID-19 increased exponentially in the month of March 2020 [2]. It has been triggered by the negative impact of COVID-19 on activities in various sectors, including the fisheries sector. The COVID-19 pandemic has caused a decline in fishery commodities and fishermen's income [3]. In fact, the percentage of Gross Domestic Product in the fisheries sector has declined by 3.62\% [4]. Since the COVID-19 pandemic is still far from over, the Government has been making various endeavors in order to maintain productivity and security in Indonesia's fisheries sector while continuing to adhere to health protocols. However, despite the COVID-19 pandemic, illegal fishing practices continue to occur unabated. Amidst the COVID-19 pandemic, perpetrators of illegal fishing have been using it as an opportunity to undertake their actions. It is evident from the increased number of fish theft cases during the COVID-19 pandemic. Based on records of the Ministry of Marine and Fishery Affairs of the Republic of Indonesia, in the period from January through April 2020 there were 37 cases and 44 foreign flag carriers were arrested during the COVID-19 pandemic. In the period January-February 2020 or before COVID-19 was declared as a pandemic, there had been 7 cases of illegal fishing. Subsequently, there were 15 cases of illegal fishing in March 2020, while in April the number increased further to 22 cases [5]. 
Accordingly, the number of illegal fishing cases in Indonesia increased by $428.5 \%$ during the COVID-19 pandemic.

The Indonesian government has demonstrated its commitment to take firm measures against illegal fishing practices during the COVID-19 pandemic. Various in-line ministries and institutions have adopted a range of legal policies in order to ensure continuous law enforcement during the COVID-19 pandemic. In the context of judicial process, the Chief Justice of the Republic of Indonesia has issued Supreme Court Circular Letter Number 1 Year 2020 serving as a legal basis for criminal law enforcement during the COVID-19 pandemic. Related to prisoners, on March 24, 2020 the Ministry of Law and Human Rights issued letter Number M.HH.PK.01.01.01-04 concerning the Temporary Suspension of Prisoners' Transfer to Prisons/Correction Centers. Furthermore, the Attorney General's Office of the Republic of Indonesia issued Attorney General's Instruction Number 5 Year 2020 concerning Policy on the Implementation of Functions and Case Handling During the COVID-19 Pandemic within the Public Prosecutors' Office of the Republic of Indonesia.

The adoption of the above specified various policies indicates the Indonesian government's commitment to implementing the salus populi suprema lex esto principle, namely that the people's safety is the law of the highest ranking. However, the legal culture of law enforcement in Indonesia at the present time tends to be positivistic, and as such it tends to disregard the law living and developing in society [6]. Due to positivist-oriented law enforcement, many cases are resolved through the criminal justice system (through penal means) [7]. However, law enforcement in Indonesia does not always rely on the penal approach in dealing with crime [8]. At the present time, Indonesia has entered the era of a new order in facing COVID-19, referred to as 'new normal'. In the era of 'new normal' members of society are allowed to conduct their regular activities, however, by adhering to certain health protocols. Similarly, in the era of 'new normal' activities in the fisheries sector need to be conducted as usual. The increase in illegal fishing practices amidst the COVID-19 pandemic poses potential threat on the sustainability of Indonesia's fishery resources. Criminal policy on illegal fishing counter-measures provided for in Law Number 45 Year 2009 juncto Law Number 31 Year 2004 concerning Fisheries (hereinafter referred to as the Fisheries Law), primarily uses penal provisions to deal with illegal fishing. Criminal sanctions are provided for in Article 84 to Article 101 setting out the criminal punishment of imprisonment for a maximum of 10 years and a fine of up to IDR20 billion. In the new normal order, such criminal policy needs to be adjusted bearing in mind the limited mobility of law enforcement which has to follow certain health protocols. Accordingly, there is a need for research capable of responding to the challenges of illegal fishing counter-measures in the 'new normal' order. The purpose of this article is to examine the ideal model for criminal policy concerning illegal fishing counter-measures under the 'new normal' order in Indonesia.

\section{Methods}

The descriptive qualitative research method with juridical-normative approach has been applied in this research. The juridical-normative approach is used to identify and describe the relevant concepts and theories related to the issue under research [9]. Data used in this research includes secondary data obtained from literature research [10] such as articles, books, laws and regulations issued during the COVID-19 pandemic [11] supported by other authentic literature. The data thus obtained is further subjected to qualitative analysis. 


\section{Results and Discussion}

\subsection{The Urgency of Adjusting Criminal Policy on Illegal Fishing Counter-measures In the 'New Normal' Order}

Criminal policy is essential an integral part of endeavors for social defense and endeavors to materialize social welfare. It can be stated, therefore, that the ultimate goal of criminal policy is social defense for the purpose of achieving social welfare [12].

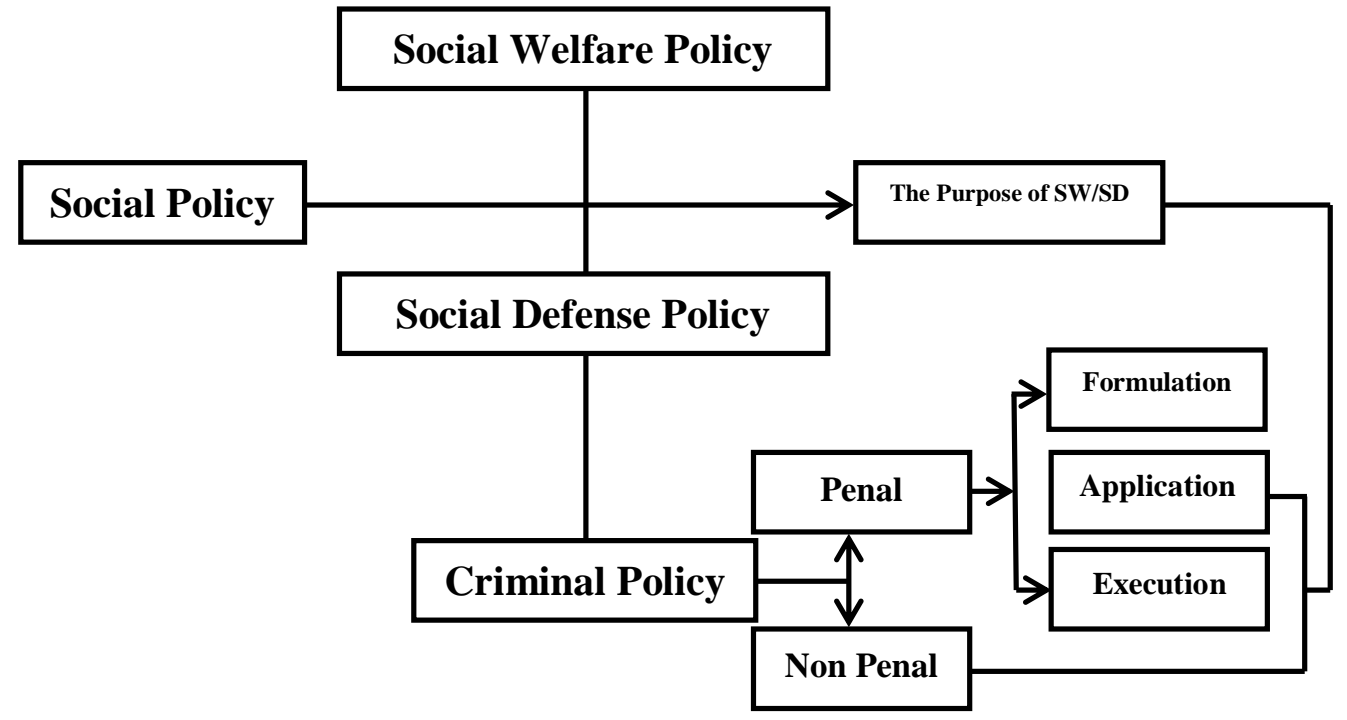

Figure 1. Scheme of criminal policy

Based on the above scheme of criminal policy, criminal counter-measures should be oriented towards achieving the goal of social defense and social welfare. Criminal countermeasures need to take an integral approach, namely striving to strike a balance between penal and non-penal measures. Criminal counter-measures take the penal approach are penal law enforcement policy the implementation of which involves formulation, application and execution [13]. Penal counter-measures put an emphasis on repressive action, while non-penal counter-measures tend to lean towards preventive measures by addressing various causingfactors of criminal acts [14].

Based on several cases of illegal fishing in Indonesia, causes of illegal fishing generally include increased fish consumption, depleted fishery resources, weak supervision, and weak law enforcement [15]. As is the case with crime in general, criminal acts of illegal fishing bring a negative impact on the environment and the state. Illegal fishing is harmful to fish preservation, to the national economy, it damages the environment and marine ecosystem, and it encroaches on Indonesia's sovereignty [16].

The COVID-19 pandemic has created serious conditions causing grave concern in Indonesia. Its negative impact has not been limited to activities in the social and economic sector; it has also affected the justice system, including the process of handling illegal fishing cases. Policy related to judicial process issued during the COVID-19 pandemic has brought an impact on investigation, prosecution and hearing of illegal fishing criminal cases in the court of law. The current criminal policy on illegal fishing counter-measures certainly requires law 
enforcers to interact with illegal fishing suspects. Fisheries Civil Servant Investigators in particular are facing certain challenges in conducting investigation. During the COVID-19 pandemic, the challenges faced by Fisheries Civil Servant Investigators include having to interact with the crew of foreign flag carriers involved in illegal fishing, limited time frame for investigation, limited time frame for detaining suspects, inadequate capacity of temporary detention centers used to accommodate perpetrators of the criminal act of illegal fishing to comply with health protocol for preventing COVID-19 transmission [5]. The Directorate General of Marine and Fishery Resources Supervision has several temporary detention centers for perpetrators of the criminal act of illegal fishing distributed among several Technical Implementation Units. The maximum capacity of temporary detention centers is up to 100 persons. Under the current COVID-19 pandemic conditions, gathering of crowds is prohibited and beds must be placed at a distance of 1.5-2 meters from one another in temporary detention centers. Such conditions result in decreased capacity, thus leading to over-loading at temporary detention centers [5]. Such overloaded conditions at temporary detention centers are contradictory to the government's policy on physical distancing [17], thus leading to a higher potential risk of COVID-19 transmission [18].

Furthermore, in order to break the COVID-19 transmission cycle, and to avoid the gathering of a larger crowd, the hearing process of illegal fishing cases is conducted virtually, which is referred to as $e$-court. Such e-court hearings have some advantages in summoning the parties, the distribution of the plaintiff's and the defendant's respective responses to arguments [19]. However, since the adoption of Government Regulation Number 21 Year 2020 concerning Large-scale Social Distancing and Presidential Decree Number 11 Year 2020 concerning the Stipulation of Public Health Emergency Situation, the process of virtual hearings has not been optimal. It has been hampered by various impediments, such as human resources, funding, infrastructure and facilities, and the extremely limited skills among people at large in operating media used in virtual hearings [20]. In addition to the above, in the context of the state's responsibility to guarantee the health of people involved in the criminal judicial process, the physical distancing policy is yet to be effective [21].

\subsection{The Ideal Model of Criminal Policy on Illegal Fishing Counter-measures in the 'New Normal' Order}

Based on the foregoing, penal policy on illegal fishing counter-measures during the COVID-19 pandemic raises several issues, as a result of which the handling of illegal fishing cases is yet to be optimal. When the penal policy fails to bring satisfactory results, the combatting of illegal fishing cases through non-penal policy can become an alternative [22]. In view of the various shortcomings of penal policy on illegal fishing counter-measures during the COVID-19 pandemic, in the current 'new normal' era several non-penal criminal policy models are offered for dealing with criminal acts of illegal fishing, which can be described as follows:

\subsection{Optimized Information Technology-based Supervision}

The Fisheries Law provides for fisheries supervision as set out in Article 66 up to and including Article 70. Supervision of the fisheries sector is conducted by fishery controllers, namely civil servants appointed by the minister of an authorized official. By virtue of Article $66 \mathrm{~B}$ of the Fisheries Law, the working area of fishery controllers includes the fisheries administrative area of the state of the Republic of Indonesia, fishing vessels, fishing ports, and/or other designated ports, fish-drying ports, fishery activity centers, fish hatchery areas, fish cultivation areas, fish processing units, and waterways conservation zones. 
At the present time, the Ministry of Maritime Affairs and Fisheries of the Republic of Indonesia has been applying technology for the prevention of various violations in the exploitation of fish resources amidst the COVID-19 pandemic. It has been done in the context of supporting supervision in Indonesia's entire maritime territory. In the center of the said supervision activities has been the fisheries management territory of the State of the Republic of Indonesia (WPP NRI) 711 which includes North Natuna Sea, Natuna Regency, the Province of Riau Isles [38]. The purpose of using information technology in supervision is to ensure that local as well as foreign fishermen do not engage in illegal fishing practices in Indonesia during the COVID-19 pandemic. In conducting supervision in the North Natuna Sea, the Ministry of Maritime Affairs and Fisheries of the Republic of Indonesia has deployed five vessels, namely KP Hiu Macan 1, KP Hiu 11, KP Orca 2, KP Orca 3, and KP Hiu Macan Tutul 2. All of the above mentioned five patrol vessels are equipped with satellite-based surveillance technology, namely vessel monitoring system (VMS), automatic identification system (AIS), and satellite radars [23].

It is evident from the foregoing that the scope of the fisheries supervision are is still quite limited. Supervision can only be conducted in WPP NRI 711, whereas Indonesia possesses as many as eleven WPP NRI. It leaves 10 WPPNRI unsupervised during the current COVID-19 pandemic, namely WPPNRI 571 covering the waters of the Moluccas Strait and the Andaman Sea; WPPNRI 572 including the waters of the Indian Ocean on the West Sumatra and Sunda Straits side; WPPNRI 573 which includes the waters of the Indian Ocean on the south of Java up to the Southern part of Nusa Tenggara, the Sawu Sea and the Western part of the Timor Sea; WPPNRI 712 which includes the waters of the Java sea; WPPNRI 713 covering the waters of the Makassar Strait, Bone Gulf, the Flores Sea, and the Bali Sea; WPPNRI 714 which includes the waters of the Tolo Gulf and the Banda Sea; WPPNRI 715 which covers the waters of the Tomini Gulf, the Molucca Sea, the Halmahera Sea, the Seram Sea, and the Berau Gulf; WPPNRI 716 which includes the waters of the Sulawesi Sea and in the Northern part of the Halmahera Island; WPPNRI 717 which includes the waters of the Cendrawasih Gulf and the Pacific Ocean; WPPNRI 718 which covers the waters of the Aru Sea, the Arafuru Sea and the Eastern part of the Timor Sea.

For the purpose of preventing illegal fishing practices, the Indonesian government has had ample opportunity to learn from the experience gained in about four months of the COVID-19 pandemic affecting Indonesia for a more optimal surveillance of sea territories. The limited use of information technology in supervising fishery resources poses a challenge to the Indonesian government to find innovative ways in order to continuously safeguard Indonesia's fishery resources against illegal fishing practices amidst the COVID-19 pandemic. In addition to the above, bearing in mind that the COVID-19 pandemic has been used as a momentum by perpetrators of illegal fishing to conduct their activities, resources have become exposed to illegal fishing practices in the 'new normal' order. There has been an increasingly urgent need for innovations in information technology-based surveillance technology, as the modus operandi of criminal acts of illegal fishing are becoming increasingly complex, among other things by switching off vessel position detectors [24]. Therefore, in the context of endeavors for optimizing fishery supervision in the 'new normal' order, information technology-based surveillance innovations have become an absolute necessity. Information technology-based surveillance innovations in the fisheries sector can be introduced at surveillance posts, fishery supervision communication instruments, as well as other surveillance facilities and equipment as required [25]. 


\subsubsection{Strengthening Deliberative Democracy}

The COVID-19 pandemic has changed many activities in life as a nation, including the combatting of illegal fishing. In the face of the 'new normal' order, the government needs to make adjustments in the endeavors against illegal fishing based on non-penal means, among other things by strengthening deliberative democracy. The concept of deliberative democracy has been introduced by Habermas in order to minimize Western rationalism in capitalist-rent society [26]. According to Habermas, when law products are delegated through certain social system networks, reproduction of the law is bound to fall under the authority of those in power [27]. Deliberative democracy is a view according to which places public deliberation by citizens of equal standing as the essence of legitimacy of decision making [28]. Such model of democracy is the opposite of classical-orthodox democracy which always defines democracy in the frame of the aggression of preferences [29]. At the same time, deliberative democracy emphasizes public participation in decision making [30], whereby public participation is the essence of deliberation-based democracy [31].

In the context of illegal fishing counter-measures in the 'new normal' order, deliberationbased democracy is the means of building a mechanism which enables public participation. The Fisheries Law has laid the basis for public participation in the fight against illegal fishing. As set out in the provisions of Article 6 paragraph (2) of the Fisheries Law, the management of fisheries for fishing and fish breeding purposes must take into account customary law and/or local traditional knowledge, as well as participation by the public. However, in the current 'new normal' order, there is a need for a special policy setting out the procedures for public participation in dealing with illegal fishing. A policy which would ensure that in implementing their function, community members continue to uphold health protocols. In the 'new normal' order, community-based illegal fishing counter-measures can be materialized based on the following strategy:

a. Enhancing public awareness and knowledge about exploitation of fishery resources in an orderly and accountable manner;

b. Imparting knowledge to local as well as foreign national fishermen about state jurisdiction in water territory;

c. Optimizing the role of public in supporting supervision of fishery resources by forming supervising community-based groups (POKMASWAS);

d. Develop knowledge about the use of fishery resources from an early age;

e. Enhance active participation by the young generation in the fight against illegal fishing practices;

f. Grant appreciation and reward to community members involved in the fight against illegal fishing.

To date, the Ministry of Maritime Affairs and Fisheries has had community-based programs for the dealing with illegal fishing, namely by forming POKMASWAS. The said activity involves community members through their active involvement in combatting illegal fishing, particularly in conducting supervision. This in view of the fact that the role of the public is an absolute necessity for achieving sustainable and beneficial management of fishery resources [32]. However, in the current 'new normal' order the government needs to strengthen the role of POKMASWAS. In order to ensure that it can maximally fulfill its function in the fight against illegal fishing during this era the POSKAMASWAS needs to be equipped with adequate infrastructure and facilities. In addition to the foregoing, in order to prevent the transmission of COVID-19, POKMASWAS needs to be provided with mitigation and comprehensive education in order to be able to face up to this 'new normal' order. 


\subsection{Environment-oriented Guidance}

For the materialization of public welfare, criminal policy needs to be oriented towards protection of the public. In the current 'new normal' order, criminal policy on illegal fishing counter-measures with penal approach is facing various hurdles. Therefore, criminal policy on illegal fishing counter-measures currently provided for under the Fisheries Law needs to be shifted to non-penal measures. Non-penal measures against illegal fishing should entail environment-oriented guidance to perpetrators of illegal fishing, as well as to the criminal justice system. Such guidance can prevent perpetrators of illegal fishing from becoming subject to criminal sanctions. On the other hand, environment-oriented guidance tends to lean towards conservation of the environment due to its being focused on restoring environmental damages caused by illegal fishing. On the other hand, environment-oriented guidance can relieve the criminal justice system from case backlogs occurring due to the legal process which is limited by health protocols.

By providing environment-oriented guidance, non-penal based criminal policy can be implemented with in-situ as well as ex-situ strategy [33]. In-situ strategy consists of fishery resources management and development, securing fishery management zones, development of fish habitat and ecosystem, as well as the development of adequate infrastructure and facilities. At the same time, environment-oriented guidance $e x$-situ consists of guidance and control of illegal fishing, enhancing awareness among perpetrators of illegal fishing about the significance of fishery resources, guidance to perpetrators of illegal fishing to become fishery conservation cadres.

Non-penal policy in the form of environment-oriented guidance is a form of prevention and control of illegal acts of illegal fishing in the 'new normal' order in Indonesia. Accordingly, the government should not limit its efforts to providing guidance merely by dissemination. [34]. Rather than that, such efforts need to be increasingly focused on intensive guidance through cooperation at the regional, national and international level. In addition to the foregoing, there is a need to induce changes in public perception about activities for the exploitation of fishery resources, whereby the government needs to provide ample space and opportunity to perpetrators of illegal fishing to become part of business partnership programs. Such partnership programs can be conducted by involving perpetrators of illegal fishing and companies holding fishery permits. By doing so, former perpetrators of illegal fishing conducting their activities in the concession area of the fishery companies concerned become subordinates in fishery business activities. It would create a mutually beneficial relationship to both parties (win-win solution), to perpetrators of illegal fishing as well as fishery companies.

\section{Conclusion}

Based on the foregoing discussion of the issue at hand it can be concluded that combatting illegal fishing cases through penal measures during the COVID-19 pandemic is facing various hurdles due to limitations posed by health protocols. In view of various shortcomings experienced by penal policy in combatting illegal fishing during the pandemic, under the 'new normal' order several non-penal policy models are being offered, namely optimizing information technology-based supervision, strengthening deliberation-based democracy, and environment-oriented guidance. Non-penal based criminal policy measures are expected to be able to provide protection and welfare, particularly to fishermen as well as 
legal certainty in dealing with various hurdles in the combatting of illegal fishing in the "new normal' order in Indonesia.

\section{References}

[1] Taufik and Hardi Warsono: Birokrasi Baru Untuk New Normal: Tinjauan Model Perubahan Birokrasi Dalam Pelayanan Publik Di Era Covid-19. Vol. 2, pp. 1-18. Dialogue J. Ilmu Administrasu Publik, (2020)

[2] Mukhtar, Saparuddin, K. Y. S. Putri, Maulina Larasati Putri, Marisa Puspita Sary, Vera Wijayanti Sutjipto, S Bekti Istiyanto, and Assyifa Amelia Azzahra: Digital Social Media: Creative Economy Quarantine during the Coronavirus Pandemic.Vol. 2, pp. 416-430. Int. J. Innov. Creat. Change. (2020).

[3] Mardhia, Dwi, Neri Kautsari, Lalu Ilham Syaputra, Wahyu Ramdhani, Chandra, and Okta Rasiardhi: Penerapan Protokol Kesehatan Dan Dampak Covid-19 Terhadap Harga Komoditas Perikanan Dan Aktivitas Penangkapan. Vol. 1, pp. 80-87. Indonesian Journal of Applied Science and Technology. (2020).

[4] Sari, Deanita: Fenomena Ekonomi Dan Perdagangan Indonesia Di Masa Pandemi Corona Virus Disease-19 (Covid-19). Vol. 4. pp. 81-93. AKTIVA Jurnal Akuntansi Dan Investasi. (2020).

[5] Maronie, Sherief and Rangga Dwi Wahyuputra: Penanganan Tindak Pidana Perikanan Oleh PPNS Perikanan Di Masa Pandemi Covid-19.https://kkp.go.id/djpsdkp/artikel/19429penanganan-tindak-pidana-perikanan-oleh-ppns perikanan-di-masa-pandemi-covid-19.

[6] Rosidah, Nikmah, Amnawaty, and Rifandy Ritonga: Does the Juvenile Justice System protect Youth Supply chain? Progressive Juvenile Court Judges: Reform of the Juvenile Criminal Justice System in Indonesia through a Socio-Legal Approach supported by PLSStructural Equation Modeling. Vol. 6, pp. 216-235. International Journal of Innovation, Creativity and Change. (2019).

[7] Sahabuddin, S: Reorientasi Kebijakan Kriminal Dalam Menyelesaikan Kasus Ringan (Dari Due Process Model Ke Reintegrative Model). Vol. 14, pp. 162-175. Jurnal Dinamika Hukum. (2014).

[8] Anggaraeni, Leni, and Hilal Ramdhani: Pencegahan Money Politik dalam Pemilihan Umum Melalui Penguatan Kebijakan Penal. Vol. 4, pp. 59-68. Jurnal Komunikasi Hukum. (2018).

[9 ]Rosidah, Nikmah, Amnawaty, and Rifandy Ritonga: Progressive Juvenile Court Judges: Reform of the Juvenile Criminal Justice System in Indonesia through a Socio-Legal Approach. Vol. 5, pp. 753-768. International Journal of Innovation, Creativity and Change. (2019).

[10] Maroni, Sopian Sitepu, and Nenny Dwi Ariani: Humanistic Law Enforcement As The Application Of The Value Of Justice, Expediency And Legal Certainty Based On Pancasila. Vol. 22, pp. 1-6. Journal of Legal, Ethical and Regulatory Issues. (2019).

[11] Sartika Saimima, Ika Dewi and Noviansyah: Model Persuasif Edukatif Bagi Masyarakat Untuk Mendukung Program Asimilasi Dan Integrasi Bagi Narapidana Anak Pada Masa Pandemi Covid-19. Vol. 3, pp. 51-56. RES JUDICATA. (2020).

[12] Suharto: Analisis Kebijakan Publik Panduan Praktis Mengkaji Masalah dan Kebijakan Sosial. Bandung: Alfabeta. (2005).

[13] Sitepu, Sudirman: Penanggulangan Kejahatan Melalui Kebijakan Kriminal. Vol. 8, pp. 
325-335. Syiar Hukum. (2006).

[14] Mulyadi, Mahmud: Criminal Policy: Pendekatan Integral Penal Policy dan Non-Penal Policy dalam Penanggulangan Kejahatan Kekerasan. Medan: Pustaka Bangsa Press. (2008).

[15] Jaelani, Abdul Qodir and Udiyo Basuki: Illegal Unreported and Unregulated (IUU) Fishing: Upaya Mencegah dan Memberantas Illegal Fishing dalam Membangun Poros Maritim Indonesia. Vol. 3, pp. 176-180. Supremasi Hukum. (2014).

[16] Damanik, Riza, and Budiati Prasetiamartati: Menjala Ikan Terakhir (Sebuah Fakta Krisis di Laut Indonesia). Jakarta: WALHI. (2008).

[17] Indriaswari Susanto, Adelia Rachma, Antonius Havik Indradi, Aqshal Muhammad Arsyah, Cora Kristin Mulyani, Kevin Daffa Athilla, Muhammad Hamzah Al Faruq, Muhammad Rayhan, Natalische Ramanda R.A, and Shafira Dinda: Kajian Politik Hukum Pemerintah dalam Penanganan Pandemi Covid-19. Dewan mahasiswa Justicia Fakultas Hukum UGM. (2020).

[18] Hidayat, Risyal Hardiyanto : Langkah - Langkah Strategis Untuk Mencegah Pandemi Covid-19 Di Lembaga Pemasyarkatan Indonesia. Vol. 9, pp. 43-55. Jurnal Pendidikan Kesehatan. (2020).

[19] Anggraeni, R. D: Wabah Pandemi Covid-19, Urgensi Pelaksanaan Sidang Secara Elektronik. Vol. 4, pp. 7-12.'ADALAH. (2020).

[20] Lumbanraja, Anggita Doramia: Perkembangan Regulasi Dan Pelaksanaan Persidangan Online Di Indonesia Dan Amerika Serikat Selama Pandemi Covid-19. Vol. 2, pp. 46-58. Jurnal Crepido. (2020).

[21] Ristyawati, Aprista: Efektifitas Kebijakan Pembatasan Sosial Berskala Besar Dalam Masa Pandemi Corona Virus 2019 oleh Pemerintah Sesuai Amanat UUD NRI Tahun 1945. Vol. 3, pp. 240-249. Administrative Law \& Governance Journal. (2020).

[22] Firmansyah, Arif, and Euis D. Suhardiman: Build Politics Criminal in the Coal Mining to Welfare of Public through Means of Non-Penal. Vol. 9, pp. 293-309. Fiat Justisia. (2015).

[23] Ambari, M: Perlindungan Laut Indonesia di Tengah Wabah COVID-19. https://www.mongabay.co.id/2020/04/29/perlindungan-laut-indonesia-di-tengah-wabahcovid-19/. (2020).

[24] Azkia, Arifah: Illegal Fishing Kembali Beraksi di Tengah Pandemi. https://fokusberita.id/illegal-fishing-kembali-beraksi-di-tengah-pandemi-opini-arifah azkia/. (2020).

[25] Naim, Armain: Pengawasan Sumberdaya Perikanan Dalam Penanganan Illegal Fishing Di Perairan Provinsi Maluku Utara. Vol. 3, pp. 1-14. Jurnal Ilmiah Agribisnis Dan Perikanan. (2010).

[26] Fatkhurohman: Mengukur Kesamaan Paham Demokrasi Deliberatif, Demokrasi Pancasila Dan Demokrasi Konstitusional. Vol. 4, pp. 37-58. Jurnal Konstitusi. (2011).

[27] Haliim, Wimmy: Demokrasi Deliberatif Indonesia: Konsep Partisipasi Masyarakat Dalam Membentuk Demokrasi Dan Hukum Yang Responsif. Vol. 42, pp. 19-30. Masyarakat Indonesia. (2016).

[28] Muzaqqi, Fahrul: Diskursus Demokrasi Deliberatif Di Indonesia. Vol. 3, pp. 123-139. Jurnal Review Politik. (2013).

[29] Prasetyo, Antonius Galih: Menuju Demokrasi Rasional: Melacak Pemikiran Jürgen Habermas tentang Ruang Publik. Vol. 16, pp. 95-186. Jurnal Ilmu Sosial Dan Ilmu Politik. (2012).

[30] Dryzek, John S: Deliberative Democracy and Beyond: Liberals, Critics, Contestations. new york: Oxford University Press. (2000). 
[31] Faedlulloh, Dodi, Retnayu Prasetyanti, and Indrawati: Initiating Deliberative DemocracyBased Public Space: A Study on Dynamic Management of Child-Friendly Integrated Public Space (RPTRA) in North Jakarta. Vol. 12, pp. 43-60. Spirit Publik. (2017).

[32] Anwar, Mashuril and Maya Shafira: Harmonisasi Kebijakan Pengelolaan Lingkungan Pesisir Lampung dalam Rezim Pengelolaan Berbasis Masyarakat. Vol. 6, pp. 266-287. Jurnal Hukum Lingkungan Indonesia. (2020).

[33] Saifullah: Kebijakan Kriminal Di Bidang Konservasi Keanekaragaman Hayati. Vol. 4, pp. 95-120. Ulul Albab. (2002).

[34] Sudarmin: Optimalisasi Penanggulangan Kegiatan Penambangan Emas Illegal Secara Penal Dan Non Penal Guna Meminimalisir Konflik Sosial Di Kabupaten Bengkayang Kalimantan Barat. Vol. 3, pp. 1-22. Jurnal Nestor Magister Hukum. (2016). 